\title{
Calligraphy crafts made from waste: A case study on Sawdust
}

\author{
M.N. Hadiansyah \\ Telkom University, Bandung, Indonesia \\ P.S.T. Dewi \\ Bali Design \& Business Institute, Bali, Indonesia \\ P. Adinata \& F. Syaban \\ Telkom University, Bandung, Indonesia
}

\begin{abstract}
The problem raised in this study is wood waste from the wood industry. This industry produces building accessories such as doors, windows, and frames that are considered very useless and has a bad impact on the environment. Calligraphy craftsmen see an opportunity from this wood waste. Through the creativity of craftsmen, wood waste can be used as a craft that has a sale value. They chose sawdust as a material for making calligraphy crafts. This study aims to know how calligraphy craftsmen take advantage of furniture industry waste, namely sawdust, in order to increase the selling value so that it has an impact on increasing their economy. Through the method of the qualitative approach with a comparative method, it can be traced how the process of increasing the sale value of crafts made from sawdust by craftsmen is found in two techniques of making: molding and sticking. Both can increase the sale value of wood waste with multiple benefits. The results of the comparison show that the molding technique is more profitable in time, process, and cost.
\end{abstract}

Keywords: calligraphy, craft, wood waste, sawdust

\section{INTRODUCTION}

The definition of wood waste is the result of the remnants of human activity in making some products made from wood that have no economic value (Purwanto 2009). The production process in the craft industry of wooden furniture at the initial stage is in the form of raw material, that is raw wood in the form of spindles or pieces. In the next stage, the raw wood is processed with the latest technologies and certain equipment by the needs so that it becomes a product. The process that can't be avoided is the existence of waste from the production such as shavings, pieces of wood, and sawdust created by equipment and cutting tools such as hand saws, table saws, and other equipment used to produce wood waste in the form of powder (Sumarno 2015). The existence of mishandling wood waste has a negative impact on the environment and the community, so there is a need to think continuously about the waste material (Sutarman 2016).

Previous research on sawdust did not concentrate on its commercial value. Such sawdust was used as a medium for growing mushrooms (Taskirawati 2018), and in the study of Purba and Lubis (2018), sawdust was used as a mixture of light bricks, while Salman (2020) examined sawdust which can be made into compost for soil fertilizers.

Lately, creativity appears that changing the sawdust into a craft has a high sale value. It is a given that many people are aware of the importance of maintaining the environment so that many people are interested in crafts made from waste. One of the popular crafts in Muslim community is the sawdust calligraphy crafts. In this craft, sawdust is highlighted as the main material that can look aesthetic. Sawdust calligraphy reads Asmaul Husna, Kursi verse, Shalawat, and Tauhid sentences loved by most Muslim people, because this craft can be hanging on the wall and can 
fill the emptiness in a room (Rofiq 2019). Based on observations, there are two techniques in making sawdust calligraphy, namely molding and sticking. This study focuses on how calligraphy craftsmen take the advantage of furniture industry waste, namely sawdust in order to increase the selling value so that it has an impact on increasing their economy. Besides, it aims to find out whether the molding or the sticking that provides greater benefits for the craftsmen.

\section{RESEARCH METHOD}

The method used in this study is a qualitative approach with a comparative method. A qualitative approach is an approach based on a researcher's experience in producing a thinking perspective that is conveyed in descriptions (Creswell 2003). While the comparative method is used to compare two variables (Sugiyono 2010), in this study the variables are molding and sticking in the technique of making sawdust calligraphy.

\subsection{Data collection}

The data collection method used is the descriptive qualitative data collection method. Qualitative research is used to produce detailed data because the data comes from interviews and direct observation (Poerwandari 2007). The stages of data collection are made through observation and interviews with five manufacturers of calligraphy made from sawdust. Among them, three of them use the molding technique, while two of them use the sticking technique. During the observation, the process documentation of each technique was also carried out to support the results of the interview. Besides, data collection through a reference is also carried out to obtain data on the method of processing sawdust.

\subsection{Data analysis}

This study used a comparative method to analyze the data. Based on observations, there are two techniques in making sawdust calligraphy, namely molding and sticking. Each technique is observed for the detail of the process and the cost of production so that the differences from each technique are known. The last stage is comparing both to find out which one has the greatest benefit.

\section{RESULT AND DISCUSSION}

\subsection{Result}

Waste from the furniture industry can be categorized into a few kinds, namely: shavings, pieces of wood, sawdust, and dust. Waste like that is very difficult to reduce in the furniture industry. In the process of making the craft of calligraphy, the type of waste selected is sawdust, because sawdust has a particle size smaller than some other types of wood waste.

Sawdust calligraphy can be done using two techniques: sticking and molding. The technique of sticking is the technique of twisting sawdust dough then sticks one by one to follow the shape of the pattern on the surface of the flat field. The making of sawdust calligraphy with the sticking technique requires a few tools and materials: sawdust, wood board, wood glue, and a palette knife.

Based on Figure 1, the initial technique of making sawdust and wood glue mixed on the board and then mixed evenly using a palette knife (1). Furthermore, make a mixture of sawdust and wood glue into the dough (2), and round the dough to an elongated shape for easy to form the calligraphy on the continued process (3). Sticking a dough of sawdust round elongated shape to follow the pattern sketch on the plywood (4), using a palette knife to form the composite powder of the wood neatly and to follow the shape of the pattern. After all the patterns are covered by sawdust dough, hereinafter closing the part out of the pattern that is still empty, use the wood glue and sawdust (5). 


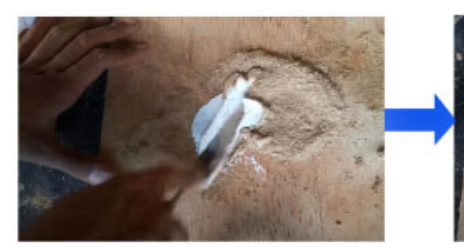

(1)

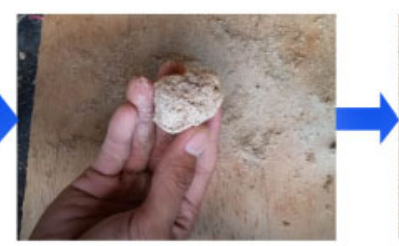

(2)

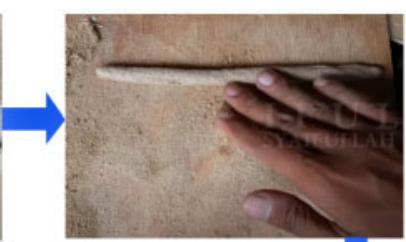

(3)

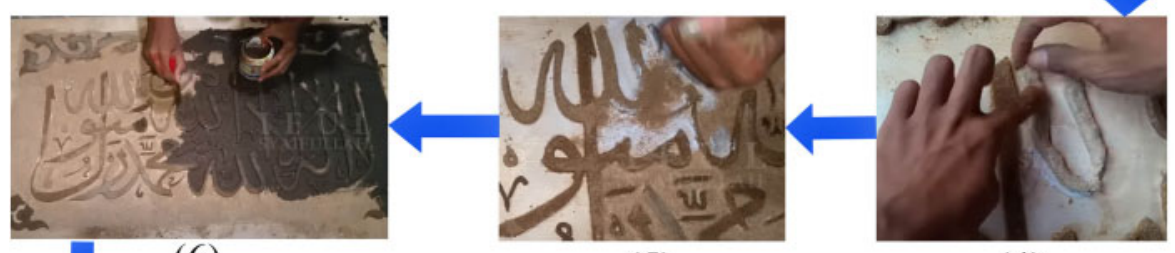

(6)

(5)

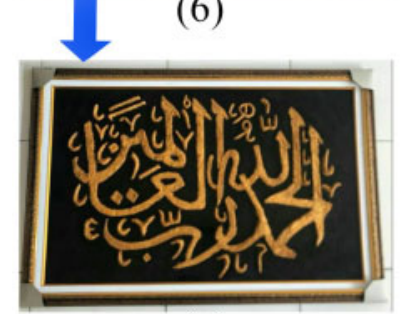

(4)

\section{(7)}

Figure 1. The stages of the sticking technique.

The next step is waiting for it to dry completely, which takes $4-5$ days. After the entire surface is dried, the next step is finishing using wall paint with a different color between the background and the calligraphy (6). The goal is to make it look more colorful and interesting (7).

The molding technique in the manufacturing of calligraphy sawdust still uses glue as a mixture for sticking. Sawdust is not strong enough to withstand stretches that are elongated and needs another mixture as the adhesive. The technique of making the calligraphy crafts made from sawdust with the molding technique requires a variety of tools and materials such as electric soldering, styrofoam, wood glue, sawdust, paper, pencil, and cutter.

Based on Figure 2, the initial technique is to draw the shape of the pattern calligraphy on paper, and then patterned paper is hollowed to follow the pattern using the cutter (1). Paper that has been hollowed out and then taped on the styrofoam. After the paper is tacked, the styrofoam is hollowed to follow the pattern of the calligraphy contained in the paper using electric soldering (2). Mix the sawdust and wood glue evenly and then fill in the molding made from styrofoam that has been made (3). After the styrofoam is filled, the next step is to dry it using sunlight (4). This process of drying takes $4-5$ days depending on the weather. The last stage is framing the calligraphy so it can be hung on the wall (5).

\subsection{Discussion}

From the comparison conducted, it was found that each technique is different. The comparison can be seen in Table 1.

The results of the comparison Table 1 show that the technique of molding is faster with a higher price than the technique of sticking. The molding technique does not use synthetic dyes. It only relies on the natural color of the sawdust that is friendly to the environment. If the sticking technique, the advantage obtained is the other result of the craft having different looks. Because the process of the sticking technique is handmade from the start to the end, it certainly is a different result. 


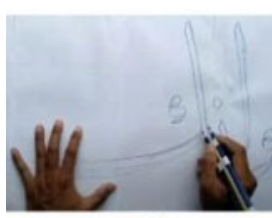

(1)

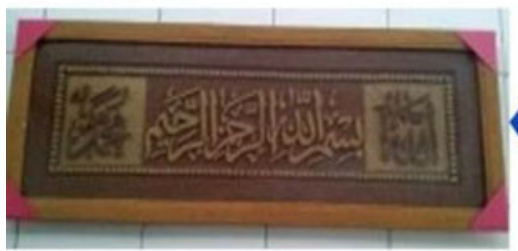

(5)

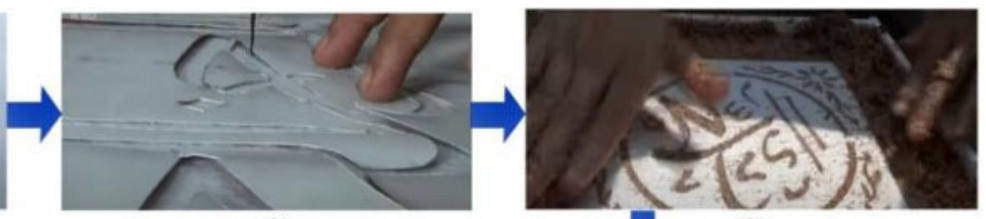

(3)

Figure 2. The stages of the molding technique.

Table 1. Comparison of sticking and molding technique.

Sticking Technique

The sticking process following the pattern in the sketch calligraphy on the wood board takes up a lot of time because one should be careful and follow the shape of the pattern manually.

After the annealing process is completed enter the process of drying after that is painted using wall paint and given a layer of spray paint clear.

The calculations of profit earned by size 1125 square inch (in IDR):

Production Cost: 147,500

Selling Price: 450,000

Profit: (selling price - production cost)

$450,000-147,500=343,500$

Percentage of profit:

$(302,500: 450,000) \times 100 \%=67.22 \%$

The percentage of profit earned by size 1125 square inch is $67.22 \%$.
Molding Technique

The process of punching holes in paper and styrofoam to be the main focus. Because if the process is not neat, the result of moldings is not neat either. The advantage of the molding technique is relatively short and does not take much time.

The molding technique does not need finishing using paint, it just needs to follow the original color on the wood so that is friendly for the environment.

The calculations of profit earned from each craft by size 1125 square inch (in IDR):

Production cost: 141,500

Selling Price: 485,000

Profit: (selling price - production cost)

$485,000-141,500=343,500$

Percentage of profit:

$(343,500: 485,000) \times 100 \%=70.82 \%$

The percentage of profit earned from each craft by size 1125 square inch is $70.82 \%$.

\section{CONCLUSION}

The type of wood industry waste chosen by calligraphy craftsmen is sawdust. Sawdust was chosen because it hasit a smooth texture and easy to shape. There are two techniques to be used in making sawdust calligraphy, namely molding and sticking. The molding technique is more profitable and faster both in terms of time and production process as well as the percentage of profit on the selling price. Comparison between the molding and the sticking with the same size, the profit of the molding is $70.82 \%$ while the sticking technique is $67.22 \%$. From these results, it can be seen that the function of sawdust can be increased through skill and creativity to make calligraphy crafts. Besides, the crafts made from waste can increase the selling value of the craft so that it is profitable and of course has an impact on improving the economy of craftsmen. 


\section{ACKNOWLEDGMENTS}

The authors gratefully acknowledge the support for this research provided by the School of the Creative Industries, Telkom University. The authors also wish to thank all colleagues and the community of craftsmen, especially wood waste craftsmen in East Java, who have contributed to this research. Thank you for all the support.

\section{REFERENCES}

Creswell, J. W. 2003. Research design: Qualitative, quantitative, and mixed methods approach (2nd ed.). Thousand Oaks, CA: Sage.

Poerwandari, K. 2007. Pendekatan Kualitatif untuk Penelitian Perilaku Manusia. Universitas Indonesia: Jakarta.

Purba, R.E.S. and Lubis, K. 2018. Pemanfaatan Limbah Serbuk Gergaji Kayu Sebagai Subtitusi Campuran Bata Ringan Kedap Suara. Buletin Utama Teknik UISU Medan (Vol. 13) https://jurnal.uisu.ac.id/index. $\mathrm{php} /$ but/article/view/277/298

Purwanto, D. 2009. Analisa Jenis Limbah Kayu pada Industri Pengolahan Kayu di Kalimantan Selatan. Jurnal Riset Industri Hasil Hutan (Vol. 1). http://dx.doi.org/10.24111/jrihh.v1i1.864

Rofiq, M. 2019. Berkah Ramadhan, Seni Kaligrafi Serbuk Kayu di Probolinggo Laris Manis. Retrieved from https://news.detik.com/berita-jawa-timur/d-4554434/berkah-ramadhan-seni-kaligrafi-serbuk-kayudi-probolinggo-laris-manis. 2020

Salman, N. 2020. Potensi Serbuk Gergaji Sebagai Bahan Pupuk Kompos. Jurnal Komposit (Vol. 4) http://dx.doi.org/10.32832/komposit.v4i1.3695

Sugiyono. 2010. Metode Penelitian Kuantitatif Kualitatif dan R\&D. Álfabeta: Bandung.

Sumarno. 2015. Inovasi Produk Kerajinan Melalui Limbah Padat (Recycle) Industri Pengolahan Kayu Jati. Jurnal Pengabdian Masyarakat Kewirausahaan Indonesia (Vol. 1). https://doi.org/10.36600/.vli1.38

Sutarman, I.W. 2016. Pemanfaatan Limbah industri Pengolahan Kayu di Kota Denpasar (Studi Kasus pada CV Aditya). Jurnal PASTI (Vol. 10). https://publikasi.mercubuana.ac.id/index.php/pasti/article/view/668/571

Taskirawati, I. 2018. Pemanfaatan Limbah Serbuk Kayu Jati (Tectona Grandis) Sebagai Media Tumbuh Jamur Tiram (Pleurotus Ostreotus). Journal Perennial (Vol. 14) https://doi.org/10.24259/perennial.v14i2.5642 